\title{
PERILAKU BETON PASKA KEBAKARAN DAN BERBAGAI ALTERNATIF SOLUSINYA
}

\author{
Oleh: Singgih Subagyo ${ }^{1}$ \\ E-mail: singgihsubagyohadi@gmail.com
}

\begin{abstract}
ABSTRAK: Seiring berkembangnya jaman, pertumbuhan disekitar kita pun cukup maju. Hal ini dapat terlihat dengan semakin kritisnya masyarakat dalam memilih bentik maupun struktur bangunan. Akan tetapi, akhir-akhir ini sering terjadi kebakaran pada bangunan yang mengakibatkan terjadinya kerusakan pada struktur, utilitas serta peralatan yang ada didalamnya dan merupakan masalah bagi pemiik bangunan. Mengingat fungsi bangunan sangat penting, maka gedung yang mengalami kebakaran cukup serius biasanya harus segera direhabilitasi. Dalam pemecahan masalah ini salah satunya dengan menggunakan beton semprot (gunite concrete) pada bangunan pasca kebakaran tujuan studi ini adalah mengevaluasi penanganan elemen struktur yang mengalami kerusakan akibat kebakaran dan untuk mencari alternative solusi yang dapat dipakai secara optimal agar stukur tetap dapat difungsikan tanpa banyak mengurangi kuat tekan beton yang ada.

Pelaksanaan studi dilakukan dengan pengumpulan data, baik data-data primer yang berupa survey lapangan dan data sekunder dari PT. Yodya Karya, sehingga penulis dapat mengetahui sejauh mana metode gunite concrete dapat digunakan pada bangunan pasca kebakaran. Penanganan struktur setelah kebakaran dengan menggunakan cara beton semprot sangat cocok karena cara beton semprot mempunyai berat jenis hampir sama dengan beton normal yaitu antara $2240 \mathrm{Kg} / \mathrm{m}^{3} \mathrm{sampai}$ dengan $2320 \mathrm{Kg} / \mathrm{m}^{3}$, mempunyai daya lekat sangat tinggi pada beton atau tembok, dan lebih ekonomis dibanding beton konvensional. Cara beton semprot juga mempunyai kemampuan untuk membentuk ikatan yang baik untuk sejumlah material serta keuntungan-keuntungan lain dalam aplikasi, fleksibility, kecepatan dalam penyelesaian dan kekuatan yang dihasilkan.
\end{abstract}

Kata-kata kunci: Pasca Kebakaran, Perilaku Beton, Solusi.

\section{PENDAHULUAN}

Kendala kebakaran dewasa ini menjadi suatu masalah bagi pemilik bangunan, dikarenakan biaya untuk membangun kembali bangunan yang telah terbakar begitu besar. Sehingga dipilih alternatif lain untuk memecahkan masalah setelah masa kebakaran. Kebakaran pada bangunan sipil adalah bahaya yang sejak dahulu selalu mengancam kehidupan manusia. Akhir-akhir ini sering terjadi kebakaran pada gedung bertingkat banyak, yang mengakibatkan terjadinya kerusakan pada struktur, utilitas, serta peralatan yang ada di dalamnya. Dalam SKBI-2.3.53.1987 terdapat pertunjuk perencanaan struktur bangunan untuk pencegahan bahaya kebakaran pada bangunan rumah dan gedung. Setiap perencanaan wajib memperhitungkan kemungkinan terjadinya bahaya kebakaran sebagai suatu pengaruh khusus dalam usaha mencegah dan menanggulangi bahaya kebakaran. Selama terjadi kebakaran suhu sekitar elemen struktur yang terbakar akan meningkat. Dengan naiknya suhu, maka sifat-sifat bahan terutama yang menyangkut kuat tekan beton dan baja akan menurun. Seberapa jauh penurunan tersebut terjadi sangat tergantung pada suhu maksimum yang pernah dicapainya.

Masalah yang akan dibahas dalam Penelitian ini adalah merencanakan tindakan apa yang perlu dilakukan untuk perkuatan, serta kemungkinan pelaksanaannya di lapangan. Setelah dilakukan perbaikan, masih perlu diadakan evaluasi kekuatan struktur terhadap beban yang harus dipikul oleh bangunan dimasa yang akan datang. Dalam penanganan suatu bangunan yang telah terbakar, sangat banyak permasalahan dalam pengerjaan perbaikannya.

1) adalah staf pengajar Program Studi Teknik Sipil Universitas Cokroaminoto Yogyakarta 
Untuk Penelitian ini penyusun membatasi ruang lingkup pembahasan sebagai berikut: Perbaikan elemen struktur yang mengalami kerusakan cukup parah yang berbahan dasar semen khususnya pada kolom dan balok dengan menggunakan teknik beton semprot.

Tujuan studi ini adalah mengevaluasi penanganan elemen struktur yang mengalami kerusakan akibat kebakaran dan untuk mencari alternative solusi yang dapat dipakai secara optimal agar stukur tetap dapat difungsikan tanpa banyak mengurangi kuat tekan beton yang ada.

\section{TINJAUAN PUSTAKA}

\subsection{Umum}

Beton digunakan sebagai bahan elemen struktur terutama untuk menahan gaya tekan, formasinya pada waktu kebakaran sangat tergantung dari agregat yang digunakan. Pengaruh suhu kebakaran pada umumnya banyak terjadi bermacam gejala seperti rompal (spalling), perubahan wana beton dan hangusnya permukaan beton. Hal ini terjadi apabila kebakaran yang dialami cukup parah.

\subsection{Penanganan}

Bahaya kebakaran gedung memang tidak diinginkan oleh semua pihak, tetapi apabila hal itu terjadi perlu penanganan terhadap hal-hal/masalah yang ditimbulkan. Penanganan dalam hal ini adalah merencanakan tindakan apa yang perlu dilakukan untuk perkuatan agar mendapatkan hasil yang maksimal tanpa mengurangi kuat tekan atau sesuai dengan kekuatan yang direncanakan semula.

\subsection{Perencanaan}

Perencanaan adalah suatu proses untuk menghasilkan penyelesaian optimal. Secara garis besar prosedur perencanaan adalah sebagai berikut:

1. Perancangan yaitu penetapan fungsi yang harus dipenuhi oleh struktur.

2. Konfigurasi struktur pra rencana yaitu penentuan letak elemen agar sesuai dengan fungsi.

3. Penentuan beban yaitu menentukan beban yang bekerja pada struktur.

4. Pemilihan batang pra rencana yang berdasarkan pemilihan ukuran batang dilakukan untuk memenuhi desain obyek seperti berat atau biaya terkecil.

5. Analisa yaitu analisa struktur menentukan aman tidaknya batang yang dipilih.

6. Penilaian yaitu apakah suatu kekuatan memenuhi hasil yang optimal.

7. Perencanaan ulang yaitu pengulangan perencanaan suatu bagian dari struktur yang dipandang perlu, karena konfigurasi struktur dan beban tertentu.

8. Keputusan akhir yaitu penentuan optimum atau tidaknya perencanaan yang dilakukan.

Dengan menggunakan prosedur perencanaan diatas maka pembangunan gedung yang telah terbakar akan mendapatkan kekuatan yang sesuai dengan rencana.

\subsection{Beton Semprot (Gunite concrete)}

Beton semprot adalah suatu campuran yang terdiri dari semen, pasir dan beberapa agregat tambahan lainnya yang disemprotkan ketempat yang akan diperbaiki dengan alat semacam pistol yang bertekanan tinggi. Beton semprot juga mempunyai berat jenis hampir sama dengan berat jenis beton normal yaitu antara $2240 \mathrm{~kg} / \mathrm{m}^{3}$ sampai dengan $2320 \mathrm{~kg} / \mathrm{m}^{3}$ dan mempunyai kuat tekan yang sangat tinggi pada beton atau tembok pada umumnya. Beton semprot biasanya mempunyai perbandingan antara semen: agregat (1:3) atau (1:4) tanpa adanya admiksture khusus. 


\subsection{Proses Terjadinya Kebakaran Dalam Bangunan Dan Penyebaran Api}

- Kebakaran dalam bangunan melibatkan semua bentuk perpindahan panas seperti konduksi dan konveksi.

- Kebakaran mulai dari suatu benda "combustible" terbakar. Karena konveksi, panas disebarkan kemana-mana.

- Lidah api yang mengenai langit-langit membantu penyebaran meluas.

- Di gedung-gedung tinggi, asap atau api menyebar cepat secara signifikan mengisi bagian-bagian cerobong (tangga, lift, ventilasi dan lain-lain).

\subsection{Pengaruh Kebakaran Terhadap Beton}

Beberapa dampak yang ditimbulkan akibat suhu kebakaran antara lain:

\section{A. Kuat tekan beton.}

Kuat tekan beton pada awal pemanasan hanya mengalami sedikit kemunduran yaitu mulai pada suhu $100^{\circ} \mathrm{C}-200^{\circ} \mathrm{C}$, baru pada suhu diatas $300^{\circ} \mathrm{C}$ terlihat dengan jelas kemunduran kekuatannya. Pada suhu antara $400^{\circ} \mathrm{C}-500^{\circ} \mathrm{C}$, kalsium hidroksida yang terbentuk pada proses hidrasi mulai terurai menjadi kalsium oksida. Pada suhu $575^{\circ} \mathrm{C}$ agregat tambahan yang mengandung kuarsa mulai mengalami perubahan struktur yang disertai dengan pengembangan volume dan pada suhu $1000^{\circ} \mathrm{C}$ beton normal praktis akan hancur.

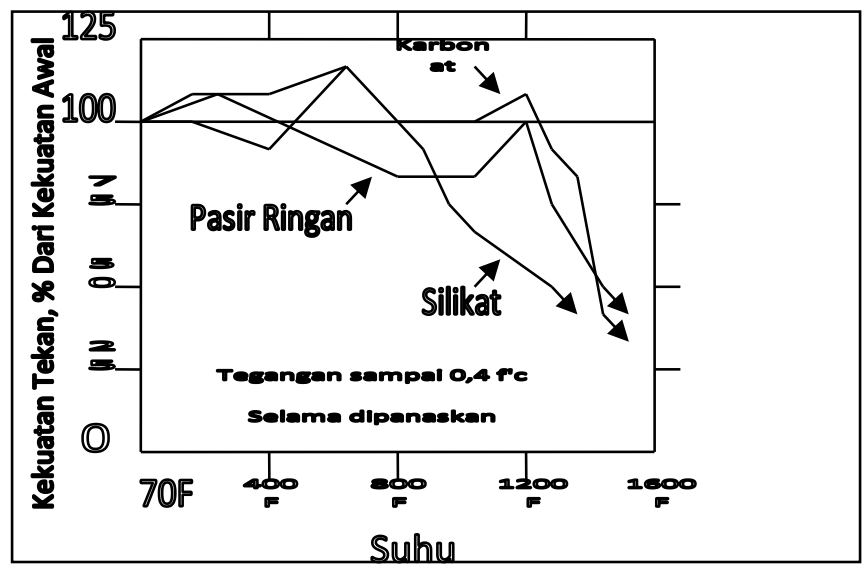

Gambar 1 Kekuatan tekan beton pada suhu tinggi Sumber: Buku Pegangan tentang Teknik Beton

\section{B. Perubahan warna beton}

Beton akan berubah warnanya apabila terbakar. Perubahan warna sangat dipengaruhi oleh jenis dan tipe dari agregat yang dipakai dalam pembuatannya. Dapat dilihat perubahan warna tersebut dalam tabel 1 dibawah ini : Dari tabel 1 terlihat bahwa suhu $300^{\circ} \mathrm{C}$ beton pada umumnya akan berwarna merah muda, apabila suhu yang dicapai dibawah $300^{\circ} \mathrm{C}$ maka pengurangan kekuatan tekan beton tidak berarti. 
Tabel: 1 Maximum Depth (In Inches) Of Concrete Showing Characteristic Changes On Heating.

\begin{tabular}{|c|c|c|c|c|}
\hline \multirow{4}{*}{ Concrete } & Maximum & \multicolumn{3}{|c|}{ Change } \\
\cline { 3 - 5 } & $\begin{array}{c}\text { surface } \\
\text { temperature } \\
\text { attained }^{\circ} \mathrm{C}\end{array}$ & $\begin{array}{c}\text { Development of } \\
\text { Pink or Red } \\
300^{\circ} \mathrm{C}\end{array}$ & $\begin{array}{c}\text { Fading of Red } \\
\text { Friability and High } \\
\text { Absorption } \\
600^{\circ} \mathrm{C}\end{array}$ & $\begin{array}{c}\text { Development of } \\
\text { Buff } \\
950^{\circ} \mathrm{C}\end{array}$ \\
\hline $\begin{array}{c}1 \text { hour } \\
2 \text { hour }\end{array}$ & 950 & 2,25 & 0,75 & 0 \\
3 hour & 1050 & 4 & 1,5 & 0,25 \\
\hline
\end{tabular}

Sumber: Gunite, A Handbook for Engineers

\section{Modulus Elastis Beton}

Penurunan modulus elastis pada beton selama kebakaran dan setelah proses pendinginan adalah sangat penting. Hal ini dapat mengakibatkan terjadinya penambahan lendutan elastis serta dapat mempengaruhi akibat lainnya. Nilai penurunannya bisa mencapai $40 \%$ apabila suhu yang pernah dicapai $300^{\circ} \mathrm{C}$ dan $60 \%$ apabila suhu mencapai $500^{\circ} \mathrm{C}$.

\section{Penjalaran Panas Pada Beton}

Suhu ruang yang dicapai pada saat terjadinya kebakaran gedung bisa lebih besar dari $900^{\circ} \mathrm{C}$. Untuk elemen pelat beton, hanya pada lapisan permukaan yang suhunya meningkat secara drastis sedangkan suhu lapisan dalamnya relatif masih rendah. Hal ini disebabkan karena pemanasan terjadi hanya dari satu pihak saja.

\section{E. Rompal (Spalling).}

Rompal pada beton saat mengalami kebakaran adalah terlepasanya material beton, besar atau kecil, bunyi letusan, dari permukaan beton yang mengalami kenaikan suhu. Dari hasil penelitian di laboratorium dan survey di lokasi-lokasi kebakaran, menunjukkan adanya dua jenis rompal, yaitu :

1. Rompal Eksplosi

Yaitu beberapa gumpalan besar dari permukaan beton.

2. Pengelupasan

Yaitu reduksi penampang melintang secara perlahan-lahan.

\section{F. Retak-Retak Pada Beton}

Pada suhu tinggi, koefisien pemuaian dari baja umumnya lebih besar dibandingkan dengan koefisien pemuaian dari beton. Hal ini menimbulkan tegangan sekunder yang dapat mengakibatkan retak-retak pada beton di daerah sekitar penulangan.

\subsection{Pengaruh Kebakaran Terhadap Baja Tulangan}

Seperti pada beton, maka perilaku baja pada suhu tinggi akan mengalami perubahan. Berbeda dengan beton, pada baja lebih mudah untuk dilakukan pengukuran perilakunya pada suhu yang steady state maupun transient.

\section{A. Kekuatan Tekan Baja}

Meski baja bahan non-combustible, tetapi tidak dapat bertahan lama pada suhu tinggi. Baja lunak misalnya bertambah kekuatannya bila suhu naik hingga $250^{\circ} \mathrm{C}$, tetapi setelah itu kekuatannya turun dengan masif hingga $50 \%$ pada suhu $500^{\circ} \mathrm{C}$. Baja pra-tekan meski kekuatannya lebih besar dari baja lunak, lebih buruk lagi performasinya. Kekuatannya turun dengan cepat pada suhu $300^{\circ} \mathrm{C}$ dan kekuatannya turun menjadi $50 \%$ pada suhu $400^{\circ} \mathrm{C}$.

\section{B. Modulus Elastis Pada Baja.}

\footnotetext{
* Suherminanta adalah Staf Pengajar pada Jurusan Teknik Sipil Fakultas Teknik Universitas Janabadra Yogyakarta
} 
Pada keadaan suhu tinggi dalam kejadian kebakaran secara otomatis akan berpengaruh, tidak hanya pada kekuatannya turun tetapi pada modulus elastisitas juga akan berpengaruh hal ini dapat dilihat pada gambar 2 berikut ini:

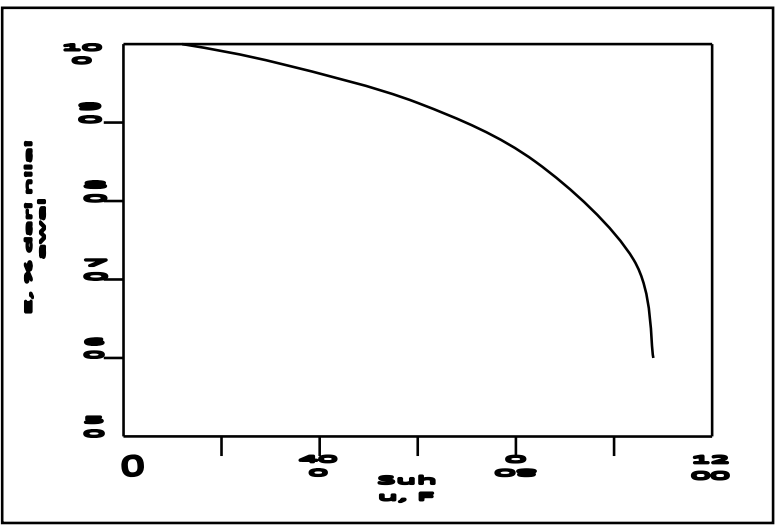

Gambar 2 Modulus elastis baja pada suhu tinggi Sumber : Buku Pegangan tentang Teknik Beton

\section{Pemuaian Pada Baja}

Terjadinya kebakaran pada bangunan sangat berpengaruh pada baja tulangan. Karena panas yang ditimbulkan oleh kebakaran tersebut semakin lama semakin tinggi, hal ini akan menimbulkan terjadinya pemuaian. Bisa kita lihat pada gambar 3 berikut.

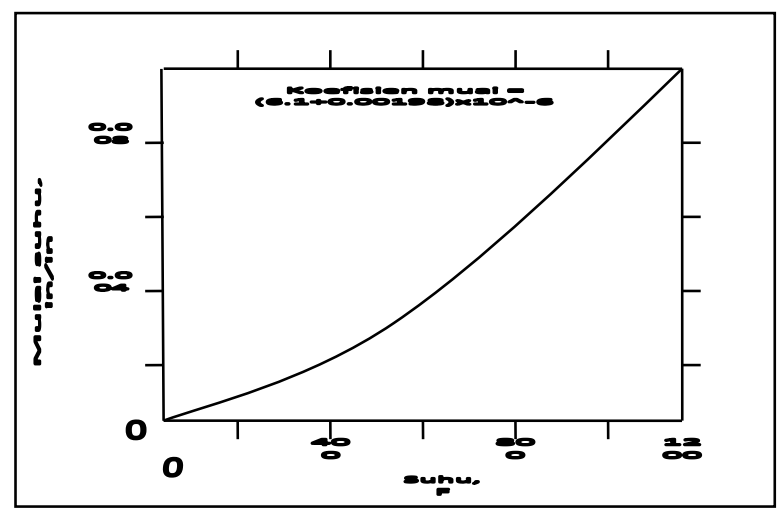

Gambar 3 Mulai suhu baja pada suhu yang semakin tinggi Sumber: Buku Pegangan tentang Teknik Beton

Gambar di atas menunjukkan bahwa pemuaian baja pada suhu tinggi, dimana semakin tinggi suhu yang dicapai pemuaian akan terus meningkat.

\subsection{Ketahanan Elemen Struktur Beton Bertulang Terhadap Suhu Tinggi}

Suatu struktur beton bertulang terdiri dari elemen pelat, balok dan kolom. Pada saat terjadinya kebakaran masing-masing elemen ini memiliki perilaku yang berbeda-beda. Ketahanan komponen bangunan terhadap api adalah sifat komponen bangunan tersebut untuk tetap bertahan terhadap api, tanpa kehilangan fungsinya sebagai struktur yang dinyatakan dalam waktu jam, 1 jam, 2 jam dan 3 jam (SKBI3.2.53.1987).

\section{LANDASAN TEORI}




\subsection{Pengukuran}

Pengukuran biasanya dilakukan jika tidak ada lagi data atau gambar bestek gedung yang bersangkutan, maka untuk dapat melakukan evaluasi struktur perlu dilakukan pembuatan gambar denah serta potongan dari struktur gedung berikut dimensi pelat, balok, kolom. Juga perlu diukur besarnya lendutan pelat lantai.

\subsection{Penyelidikan Visual}

Penyelidikan ini merupakan langkah awal yang menjadi dasar untuk melangkah ke pekerjaan selanjutnya dan sebaiknya dilakukan sesegera mungkin setelah kebakaran terjadi, ketika sisa-sisa kebakaran belum dibersihkan. Dari hasil pengamatan dapat diperoleh data antara lain :

- Bagian gedung yang mengalami kebakaran hebat.

- Bagian elemen-elemen struktur yang rusak berat.

- Kesalahan konstruksi terdahulu

- Kondisi plesteran pada dinding dan kolom yang terbakar serta retak-retak pada balok dan pelat lantai, terutama yang menunjukkan pola retak penampang

- Warna beton yang terbakar dapat menunjukkan tinggi suhu ketika kebakaran.

- Dari kondisi, posisi serta dengan diketahuinya titik leleh dan titik nyala dari material reruntuhan, maka dapat diperkirakan lamanya kebakaran dan suhu maksimum yang tercapai selama kebakaran.

\subsection{Pengujian Dengan Cara Non Destruktif.}

\section{A. Pengujian Ultrasonik}

Pengujian ultrasonik sebaiknya dilakukan pada bagian elemen struktur baik yang terbakar maupun tidak, terutama untuk areal-areal kritis. Elemen struktur yang diuji, dicatat lamanya dengan waktu (mikro detik) yang dibutuhkan gelombang ultrasonik yang melewati material. Beberapa faktor yang mempengaruhi ketepatan hasil pengujian adalah agregat dan kelembaban.

B. Pengujian Palu Beton (Hammer Test)

Pengujian palu beton bertujuan untuk mengetahui kekuatan beton pada bagian permukaan. Hal ini tidak dapat mewakili kekuatan tekan beton secara keseluruhan. Oleh sebab itu hanya digunakan sebagai pembanding terhadap hasil pengujian ultrasonik.

\section{Pengujian Selimut Beton}

Pengujian selimut beton dilakukan pada pelat, balok dan kolom, terutama yang mengalami kerusakan (keropos) menurut pengujian ultrasonik. Pengujian ini bertujuan untuk mengetahui : tebal selimut beton, jenis baja tulangan, lokasi tulangan, dan diameter dari baja tulangan.

D. Pengujian Korosi

Pengujian korosi bertujuan untuk mengetahui daya lekat antara baja tulangan dengan beton, serta tingkat korosi dari tulangan tersebut. Pengujian ini dilakukan pada pelat, balok dan kolom, baik pada bagian yang terbakar maupun tidak. Terutama pada lokasi beton yang tidak terlindung oleh selimut beton.

\subsection{Pengujian Dengan Cara Destruktif}

Metode ini hanya dapat dilakukan pada bagian elemen struktur yang apabila diambil sampelnya tidak akan menyebabkan struktur mengalami runtuh.

Pemeriksaan dengan cara destruktif yang sering dilakukan adalah:

\section{A. Pengeboran Inti Beton}

Cara yang sering dilakukan karena dapat memberikan gambaran kondisi bagian dalam struktur beton, hal ini berkaitan dengan estimasi kekuatan beton secara langsung di lapangan. Dapat juga mengetahui berat jenis, kemampuan menyerap 
air serta kekuatan lenturnya. Benda uji diperoleh dengan cara mengebor elemen struktur.

\section{B. Metode Thermoluminescence}

Pengujian ini bertujuan untuk mengetahui suhu maksimum yang pernah dicapai oleh beton walaupun tidak terjadi kerusakan, dan sejauh mana penetrasi panasnya ke dalam elemen struktur.

\subsection{Percobaan Pembebanan}

\section{A. Pembebanan Tetap}

Untuk struktur beton bertingkat biasa dilakukan percobaan pembebanan tetap pada elemen struktur lantai, karena lantai merupakan elemen paling kritis. Baik ditinjau dari akibat penetrasi panas maupun fungsinya sebagai pendukung beban-beban. Selain itu apabila terjadi kegagalan struktur, maka tidak membahayakan struktur secara keseluruhan.

\section{B. Uji Kejut}

Uji kejut bertujuan untuk meneliti kekakuan-kekakuan balok dan kolom beton, selain itu juga untuk mengetahui integritas dari balok dan kolom telah terjadi kerusakan.

\section{Uji Getar}

Uji getar berkaitan erat dengan uji kejut. Uji getar adalah pengujian menyeluruh terhadap elemen-elemen struktur dari bangunan untuk mengetahui kekakuan dan kemampuan memikul beban dari elemen struktur yang diuji.

\subsection{Metode Perbaikan Dan Teknik Pelaksanaannya}

\section{A. Agregat}

1. Penempatan Dan Penyimpanan Bahan-Bahan Beton

Penepatan dan penyimpanan bahan-bahan beton perlu diperhatikan, sebab kesalahan penempatan dan penyimpanan akan merugikan hasil beton yang dibuat, misalkan dapat menyebabkan kurang homogennya dan menurunnya kualitas beton.

2. Penakaran

Untuk mencapai kekuatan beton tertentu, kualitas K225 diperlukan perbandingan $1: 41 / 2$ berdasarkan volume atau $1: 4$ berdasarkan berat. Ini digunakan untuk manfaat umum.

3. Pencampuran

Peralatan harus dapat mencampur secara merata antara pasir dan semen sehingga butir-butir pasir terlapisi dengan sempurna. Campuran harus tersaring untuk mencegah bahan-bahan kasar ikut masuk. Campuran dengan tangan dapat digunakan karena lebih ekonomis.

\section{B. Pelaksanaan}

1. Penulangan

Jika kerusakan yang terjadi sangat parah, dimana tulangannya terlihat dengan jelas setelah dibersihkan, jarak dan ukurannya sudah tidak memenuhi persyaratan, maka tulangan tersebut dianggap tidak lagi memberikan sumbangan kekuatan, walaupun dibuktikan dengan bahwa beton semprot dapat mengikatnya secara sempurna.

2. Nozzleman

Nozzleman harus mengerti teknik penyemprotan karena ini mempengaruhi gunite yang dihasilkan. Dalam melakukan pekerjaan, nozzleman mempunyai sejumlah keputusan yang harus diambil, dengan ukuran nozzle yang digunakan, penempatan alat sehingga sesuai dengan program penembakan. Biasanya penyemprotan akan dilakukan dari dasar ke atas untuk permukaan beton. Tekanan saluran udara yang dioperasikan di saluran tidak boleh lebih kecil dari $2400 \mathrm{Kg} / \mathrm{m}^{2}$. 
3. Penembakan

Permukaan yang akan ditembak harus diberi pembasahan pada permukaannya. Posisi nozzle yang baik antara 0,6 - 1,2meter dari permukaan kerja dengan penembakan secara berirama dari sisi ke sisi dan naik turunnya agar gunite merata.

4. Rebound (Guguran Mortal)

Rebound adalah material yang tidak melekat pada pokoknya atau pada penompang gunite itu sendiri, tetapi lepas kembali dan jatuh di sekitar lapisan daerah kerja. Rebound dipengaruhi oleh: efisiensi hidrasi, perbandingan air dan semen, jenis pasir, tekanan penembakan, sudut, jarak penyemprotan, keahlian nozzleman

5. Penyumbatan

Jika peralatan dalam keadaan bersih maka kemungkinan sangat kecil terjadi hambatan karena penyumbatan. Namun jika penyumbatan itu terjadi biasanya disebabkan karena: partikel yang ukurannya terlalu besar, pasir yang sangat basah, pasir terlalu kering dan selang yang melilit.

6. Penyambungan

Penyambungan dapat dilakukan pada gunite dengan hasil memuaskan. Nilai standarnya yaitu dengan penembakan gunite sampai mencapai lebar kemiringn $20 \mathrm{~cm}-30 \mathrm{~cm}$ untuk ketebalan $7,5 \mathrm{~cm}$, dengan perbandingan yang semakin tebal semakin lebar.

7. Finishing

Lapisan yang kaya dengan semen basah akan menimbulkan keretakan pada proses pengeringan karena penyusutan yang terjadi. Untuk menghindari hal tersebut, biasanya setelah gunite dibiarkan beberapa saat \pm 1 jam pada permukaannya dilakukan penyikatan dengan sikat halus. Hal ini akan menghilangkan debu rebound dan mencegah keretakan.

\section{CARA STUDI}

\subsection{Gambaran Umum Bangunan}

Bangunan yang mengalami kebakaran dimisalkan terdiri dari 4 lantai, yaitu lantai dasar, lantai 1, lantai 2, dan lantai 3. Sebagian besar berlantai 3, sedangkan bagian depan berlantai 4, dengan ukuran $102 \mathrm{~m} \mathrm{X} 145 \mathrm{~m}$. Struktur utama adalah beton bertulang dengan pelat lantai terbuat dari struktur komposit baja bodek-beton sedangkan struktur atap terbuat dari baja. Karena bahan-bahan yang berada di dalam gedung mudah terbakar, maka suhu saat kebakaran cukup tinggi dan berlangsung cukup lama, sehingga menyebabkan:

1. Sebagian besar struktur atap runtuh.

2. Struktur pelat yang terbuat dari komposit bondek-beton berlubang dan rusak berat.

3. Mutu beton dan baja tulangan menurun.

4. Di beberapa tempat terjadi kerusakan balok.

5. Korosi baja tulangan akibat genagan air yang mengandung garam, dan kotoran bekas kebakaran lainnya.

\subsection{Jenis Data}

Kebakaran gedung telah mengalami kerusakan karena terbakar, dilakukan beberapa tindakan sebagai berikut:

1. Kunjungan lapangan dan pengamatan visual kerusakan bangunan. 
2. Pengumpulan data sekunder yang berkaitan dengan dimensi elemen struktur, penulangan, hal-hal khusus jika diperlukan dan mutu serta cara pelaksanaan pembangunan.

3. Meneliti suhu dan sebaran kebakaran pada seluruh area bangunan.

4. Pengumpulan data primer berupa pengambilan sampel dan pengujian di lapangan maupun di laboratorium.

5. Analisis hasil pengujian lapangan dan laboratorium.

6. Analisis keamanan dan kekuatan struktur existing dengan memperhatikan kerusakan dan kualitas beton dan baja di lapangan saat ini.

7. Penentuan tingkat kerusakan masing-masing elemen struktur (kolom, balok induk, balok anak dan pelat lantai).

8. Penentuan metode perbaikan/perkuatan beserta gambar-gambar dan penjelasan cara pelaksanaannya serta spesifikasi teknisnya.

9. Perhitungan volume kebutuhan perbaikan dan perkuatan struktur.

\subsection{Pelaksanaan Pengujian}

\section{A. Pengujian lapangan}

Penjelasan singkat mengenai pengujian yang meliput cara kerja dan letak pengujian yang akan dilakukan adalah sebagai berikut:

1. Pengujian Tidak Merusak (Non Destructive Test)

\section{a. Schmidt Hammer}

Bekerjanya alat ini berdasarkan 65amper pantulan dari massa pada sebuah pegas yang dikenakan pada permukaan struktur beton. Hasil pembacaan pantulan menunjukkan tingkat kekerasan dan kuat tekan beton. Pengujian Schmidt Hammer dilakukan pada kolom, balok induk, balok anak dan pelat lantai.

b. PUNDIT (Portable Ultrasonic Non Destructive Instrument Testing)

Alat ini bekerja berdasarkan prinsip perambatan gelombang ultrasonic antara pemancar (transmitter) dan penerima (receiver) lewat media beton dengan jarak tertentu. Kecepatan rambat gelombang ini dapat dikorelasikan dengan modulus elastisitas, kuat tekan beton, retak dan rongga dalam beton.

c. Rebar Locator

Alat ini digunakan untuk mendeteksi letak, diameter dan jumlah baja tulangan serta tebal selimut beton. Selain itu, alat ini juga dapat digunakan untuk membantu menentukan posisi pengambilan sampel beton inti/core case agar tidak memotong baja tulangan.

d. Microcrackmeter

Alat ini digunakan untuk mengukur lebar retak yang berukuran kecil. Alat ini dilengkapi dengan lampu sehingga dapat digunakan pada daerah yang gelap.

e. Pengukuran Lendutan

Pengukuran lendutan dilakukan pada bagian bawah balok dan pelat untuk mengetahui sejauh mana lendutan di lapangan telah terjadi. Untuk tujuan ini digunakan alat benang dan alat pengukur lendutan.

2. Pengujian Setengah Merusak (Semi Destruction Test)

a. Core Cass dan Core Drill

Pengambilan inti beton dengan alat bor dengan diameter 35-75 mm (core case) dan 100-150 mm (core drill) untuk mendapatkan silinder inti beton di lapangan. Dengan silinder inti beton ini dapat diamati kerusakan secara visual, misalnya porositas, homogenitas agregat, kepadatan dan retak/keropos pada beton serta seberapa dalam pengaruh kebakaran pada beton. Spesimen silinder kemudian diratakan pada semua ujungnya dan diuji tekan di laboratorium untuk mengetahui kuat tekan betonnya. 
b. Pengujian Tarik Baja Tulangan dan Bondek

Kualitas baja tulangan dan bondek yang digunakan pada bangunan dapat diketahui dengan cara mengambil beberapa sampel kemudian diuji tarik untuk mengetahui kuat tarik, sifat keliatan baja tulangan dan modulus elastisitasnya. Pengambilan akan dilakukan pada daerah yang tidak terbakar, dan daerah yang terbakar.

\section{B. Pengujian Laboratorium}

1. Pengujian Kuat Tekan Beton

Pengujian kuat tekan dilakukan dengan mesin uji tekan. Jika ukuran benda uji tekan tidak sama dengan ukuran standar tersebut, kuat tekan hasil pengujian masih harus dikalikan dengan anngka koreksi. Ada dua angka koreksi, yaitu:

a. Faktor koreksi yang memperhitungkan perbandingan tinggi dan diameter silinder sampel beton $\mathrm{h} / \mathrm{d}$.

b. Faktor koreksi yang memperhitungkan diameter silinder sampel beton.

2. Pengujian Kuat Tarik Baja Tulangan

Untuk mengetahui kurva hubungan tegangan-regangan baja tulangan, dilakukan pengujian tarik. Dari kurva tegangan-regangan ini akan dapat diketahui tegangan leleh, kuat tarik, regangan saat leleh dan regangan putus serta modulus elastisitas. Diambil tiga buah sampel baja tulangan dari gedung yang sudah terbakar tersebut masing-masing dengan panjang sekitar $50 \mathrm{~cm}$. Tulangan diambil dari balok dan pelat lantai yang diperkirakan pernah mengalami pembakaran dengan suhu tinggi. Tulangan kolom dan balok berupa ulir, sedangkan tulangan pelat berupa polos berdiameter $6 \mathrm{~mm}$.

\subsection{Reanalisis Struktur}

Reanalisis struktur gedung dilakukan dengan tujuan untuk mengevaluasi keamanan struktur dengan memperhatikan material setelah mengalami kebakaran, perubahan-perubahan bentuk bangunan akibat dibuat jalan di tengah bangunan sebagai akses pemadam kebakaran dan perubahan fungsi bagian-bagian bangunan.

\subsection{Pedoman Perbaikan dan Perkuatan Struktur}

Pemilihan metode perbaikan dan perkuatan disesuikan dengan kondisi lapangan dan perubahan-perubahan yang terjadi karena kebutuhan arsitektur, misalnya dilakukan pemisahan bangunan untuk mendapatkan sirkulasi udara dan sinar yang lebih baik serta jalan untuk akses pemadam kebakaran.

\subsection{Hasil Pengujian}

\section{A. Hasil Pengamatan Visual di Lapangan}

Pengamatan visual di lapangan dilakukan untuk mengetahui jenis dan tingkat kerusakan struktur, sebaran dan suhu kebakaran secara umum. Selain itu pengamatan visual bertujuan juga untuk menentukan lokasi pengujian lapangan dan jenis alat pengujian yang diperlukan dalam rangka pengujian material bangunan.

\section{B. Hasil Pengujian Material}

\section{Beton}

Untuk mengetahui kualitas beton pasca kebakaran, dilakukan pengujian beton dengan dua cara yaitu pengujian lapangan dan pengujian laboratorium. Pengujiam lapangan dilakukan dengan mengetok-ngetok atau memukul permukaan beton dengan palu dan pengujian dengan alat Schmidt Hammer pada kolom-kolom dan balok di lantai dasar, lantai 1 dan lantai 2. Pengujian laboratorium dilakukan terhadap sampel inti beton core case/core drill. Kemudian dilakukan pengujian tekan untuk mendapatkan nilai kuat tekan beton pada struktur eksisting setelah mengalai kebakaran. Setelah mengetahui hasil pengujian material baik pengujian lapangan maupun pengujian laboratorium 
tersebut di atas, diambil nilai kuat tekan beton sebesar $11 \mathrm{Mpa}$ untuk balok induk dan balok anak, dan 12 Mpa untuk kolom.

2. Tulangan Baja

Untuk mengetahui kuat leleh baja tulangan, modulus elastisitas, dan sifat lainnya dilakukan pengujian tarik terhadap baja tulangan. Diambil beberapa buah sampel tulangan baja dari gedung yang sudah terbakar tersebut masing-masing dengan panjang sekitar $50 \mathrm{~cm}$. Tulangan diambil dari balok dan pelat lantai yang diperkirakan pernah terbakar dengan suhu tinggi. Selanjutnya sampel tulangan diuji tarik di Laboratorium Bahan Bangunan. Hasil pengujian menunjukkan tulangan baja memiliki kuat leleh yang cukup tinggi. Untuk perhitungan kapasitas dan desain balok digunakan tegangan leleh fy = $460 \mathrm{Mpa}$.

\section{PERBAIKAN DAN PERKUATAN}

\subsection{Umum}

Dari hasil pengamatan visual, pengujian di lapangan dan di laboratorium serta analisis struktur, dapat diketahui apakah komponen-komponen struktur yang berupa kolom, balok masih aman atau kuat memikul beban, perlu perbaikan atau perkuatan. Perbaikan diperlukan untuk mengembalikan komponen pada kondisi semula, sedangkan perkuatan diperlukan jika diperlukan penambahan kekuatan akibat perubahan fungsi atau beban. Batasan yang mengikat dalam perbaikan/perkuatan antara lain beban secara keseluruhan yang tidak boleh lebih besar dibandingkan beban sebelumnya, karena tidak dilakukan evaluasi khusus terhadap pondasi dan tanah di bawah bangunan. Metode perbaikan dan perkuatan Gedung ini dipilih sedemikian rupa sehingga tidak menaikkan beban ke kolom maupun ke pondasi.

\subsection{Perbaikan Pelat Lantai}

Kerusakan pada pelat lantai pada area yang terbakar sebagian besar parah, karena terjadi pemisahan antara balok bondek dengan beton di atasnya. Bondek yang terpasang terlepas dari betonnya, sehingga tidak mampu lagi menahan gaya geser pada bidang pertemuan antara kedua bahan ini. Pada awal perbaikan pelat lantai, yang penting dipertimbangkan, yaitu : menggunakan pelat beton cor setempat, pelat beton pracetak dengan metode half slab dan menggunakan pelat beton komposit dengan bondek. Selanjutnya ketiga perbaikan tersebut dipertimbangkan dengan segala konsekuensinya, salah satunya dengan pertimbangan berat sendiri lantai. Alternatif yang paling memungkinkan untuk dapat dilaksanakan dengan kualitas yang baik adalah kembali menggunakan pelat komposit beton-bondek. Namun pemasangan bondek dengan metode yang tepat agar bondek tidak dipotong pendek-pendek. Bondek akan menumpang sepenuhnya di atas balok, dan antar sambungan bondek diberikan overlap sekitar $3-4 \mathrm{~cm}$. Posisi bondek di atas balokbalok akan diberi shear connector sehingga diperoleh hubungan yang baik dengan balok-baloknya.

\subsection{Perbaikan Balok}

\section{A. Injeksi.}

Untuk balok-balok yang retak penampang (retak yang tembus pada kedua sisi samping balok), retak yang menyebar dengan jumlah yang tidak terlalu banyak dan selimut beton belum mengalami spalling. Bahan yang digunakan untuk injeksi adalah epoxy. Bahan ini mudah diperoleh, misalnya produk PT Sika atau PT Fosroc.

\section{B. Drypacking}

Yaitu perbaikan sampai dengan beton baru pada tempat-tempat yang keropos, spalling atau kerusakan permukaan. Perbaikan cara ini dilakukan dengan membersihkan dan membongkar bagian yang rusak, dibersihkan kemudian diisi 
dengan kerikil dengan diameter kecil, maksimum $20 \mathrm{~mm}$. Kemudian sela-sela antar kerikil diisi dengan bahan injeksi epoxy sampai penuh. Agar kerikil dan bahan injeksi tidak lepas, perlu diberi bahan penutup/bekisting yang cukup kuat.

\section{Pembongkaran dan dicor baru}

Beton pada bagian yang rusak dibongkar dengan cara yang tidak banyak menimbulkan getaran pada bagian lainnya, kemudian baja tulangan dibersihkan. Permukaan beton lama bekas pembongkaran dibersihkan terlebih dahulu dengan air compressor, kemudian dilapisi bonding agent terus dicor dengan beton baru dengan mutu beton minimal K-275. Volume atau panjang pembogkaran balok sesuai dengan tingkat kerusakannya, dibedakan menjadi:

- $100 \%$, seluruh balok dibongkar dan dicor baru

- $\quad 50 \%$, sekitar setengah panjang balok dibongkar dan dicor baru

- $\quad 30 \%$, sekitar sepertiga panjang balok dibongkar dan dicor baru

\subsection{Perbaikan kolom}

Perbaikan yang dilakukan adalah dimulai dengan mengelupas selimut beton, dilakukan sampai tulangan sengkang kolom terlihat. Selanjutnya dipasang tulangan tambahan dan diikat menggunakan sengkang baru. Selanjutnya dipasang cetakan beton dan diberi lubang atau bukaan pada tempat-tempat tertentu dari cetakan untuk tempat masuknya beton. Pengecoran dilakukan dengan menggunakan beton bermutu K-275 dengan diameter agregat maksimal $2 \mathrm{~cm}$. Akan tetapi, dalam proses pengecoran terhadap struktur yang mengalami rusak parah pada gedung hanya sebagian saja yang menggunakan cara tersebut. Apabila dalam pelaksanaan mengalami kesulitan di dalam membuat model bekisting atau tebal beton cor yang akan dituangkan terlalu tipis, maka salah satu alternatifnya adalah dengan menggunakan metode Beton Semprot (Gunite Concrete).

\subsection{Beton Semprot (Gunite Concrete)}

Beton semprot adalah beton berkoral halus yang dengan bantuan tekanan udara dengan kecepatan tinggi disemprotkan ke lapisan dasar melalui pipa saluran dan kepala semprotan.

\section{A. Wilayah Penerapan}

Beton semprot sering digunakan bila, mendapat kesulitan dalam membuat model bekisting atau tebal beton cor yang akan dituangkan terlalu tipis. Beberapa penerapan beton semprot adalah:

- bentuk struktur tidak teratur

- pemberian penutup beton tambahan

- penguatan struktur dengan permukaan lapisan beton ekstra yang diberi tulangan ekstra

- perlindungan terhadap kerusakan mekanis

- pengisian celah-celah

- daya tahan api struktur ditingkatkan

- pemberian lapisan pelindung ekstra dan pemberian lapisan keausan

\section{B. Sistem Pengerjaan}

Ada dua metode yang berbeda untuk pengerjaan beton semprot. Metode yang paling tua adalah metode "kering". Sekitar tahun 1950 dikembangkan metode "basah".

Keuntungan dan kerugian dari metode basah dan kering, adalah:

$\begin{array}{lll}\text { Perbandingan } & \text { "kering" } & \text { "basah" } \\ \text { - pantulan } & 15-30 \% & 10-15 \% \\ \text { - rekatan } & \text { baik } & \text { banyak masalah } \\ \text { - tebal lapisan } & \text { lapisan tebal } & \text { lapisan kecil } \\ \text { penyemprotan } & \text { kemungkinan } & \text { pengendapan }\end{array}$

68 Perilaku beton paska kebakaran dan berbagai alternatif solusinya (Singgih Subagyo) 
- faktor air semen

- bahan tambahan

- mesin pembersih

- keterampilan tukang

penyemprot kebanyakan rendah

tidak perlu

sedikit waktu

pekerja yang

terlatih baik kebanyakan tinggi

perlu (mempercepat)

memerlukan banyak

waktu

tidak butuh pekerja

yang terampil

Pada gedung pasar induk Wonosobo, dengan mempertimbangkan keuntungan dan kerugian dari kedua metode di atas, maka pihak kontraktor lebih memilih menggunakan metode "kering".

C. Perawatan Sebelumnya

Sebelum mulai melakukan beton semprot, permukaan beton harus dirawat terlebih dahulu. Langkahnya adalah:

- terlebih dahulu permukaan beton dibersihkan,

- dikasarkan dan bagian-bagian yang lepas disingkirkan,

- permukaan beton "lama" dilembabkan dengan teliti dan selam 6-8 jam. Poripori harus jenuh, tetapi permukaan tidak boleh basah.

\section{Susunan Beton Semprot}

Beton semprot adalah suatu campuran dari semen, pasir, agregat kasar (besar butiran $<10 \mathrm{~mm}$ ), kadang-kadang dilengkapi dengan bahan kimia pembantu. Pilihan butiran terbesar dari bahan tambahan kasar tergantung juga pada: ketebalan $69 a m p e r$ lapisan beton semprot, ruangan diantara tulangan yang diletakan pada permukaan beton atau begisting dan penutup tulangan. Sebagai pedoman untuk ukuran koral terbesar dapat dipakai bahwa koral tidak boleh lebih besar dari pada $1 / 4$ a $1 / 3 \mathrm{~d}$.

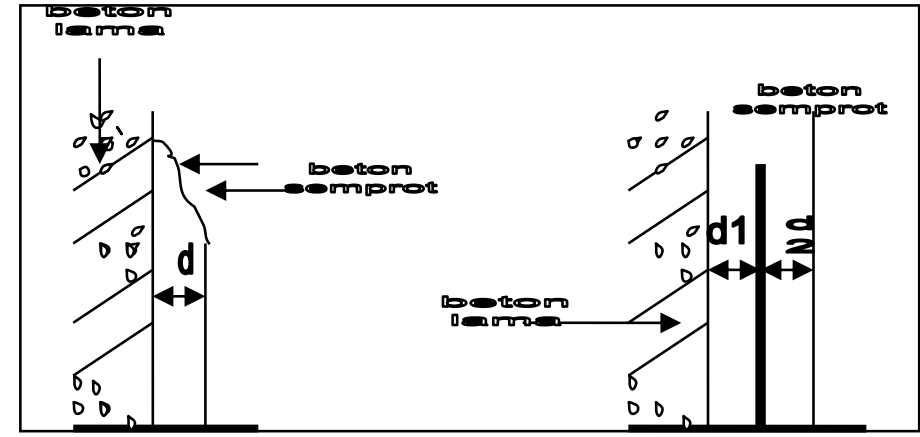

Gambar 4 Penentuan butiran terbesar dari kerikil

Kadar semen yang digunakan antara $350 \mathrm{~kg} / \mathrm{m}^{3}$ dan $400 \mathrm{~kg} / \mathrm{m}^{3}$ dan untuk mencegah pengendapan beton semprot, 69amper air semen harus rendah. Faktor air semen terletak di antara 0,3 dan 0,4.

\section{E. Pemeriksaan Beton Semprot}

Dengan bantuan kubus-kubus, percobaan beton semprot diuji kuat tekan dan rembesan airnya. Suatu metode pemeriksaan kuat rekatan adalah dengan 69amper silinder-silinder di tempat pekerjaan (misalnya $\varnothing 50 \mathrm{~mm}$ ). Tinggi silinder adalah tebal beton semprot $+50 \mathrm{~mm}$ beton "lama". Bila patahan terjadi pada bidang rekat, maka tegangan patah dapat dihitung dengan gaya tarik dibagi luas penampang silinder.

Dalam bentuk rumus:

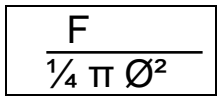




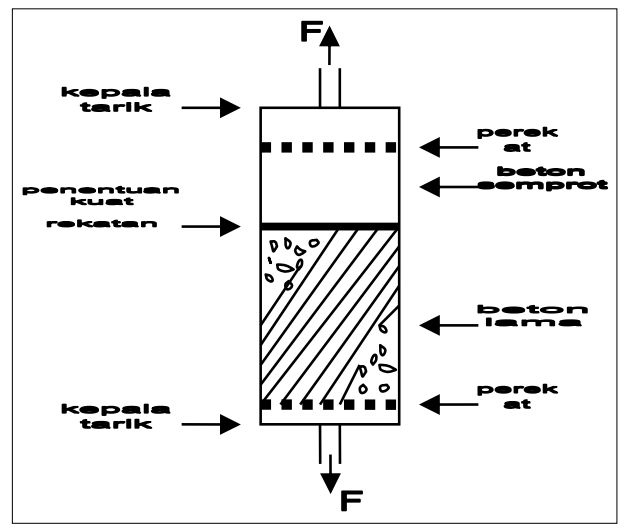

Gambar 5 Contoh penentuan kuat rekat.

\section{F. Pelaksanaan/penyemprotan}

Pada penyemprotan beton, peranan penyemrot adalah hal yang sangat penting. Keterampilan pekerja/penyemprot menentukan sebagian besar kualitas lapisan beton semprot. Dalam penyemprotan, faktor-faktor yang penting adalah: jarak antara kepala semprot dengan permukaan yang akan disemprot, arah semprot dan jumlah air.

\section{G. Tebal Lapisan}

Berkaitan dengan bahaya pengeringan dan penyusutan dituntut minimal tebal lapisan $15 \mathrm{~mm}$. Penyemprot berdasarkan pengalamannya akan mengetahui sampai berapa maksimal ketebalan yang dapat ia penuhi. Tebal maksimal ini antara lain tergantung pada; apakah pekerjaan itu "menengadah" (di atas kepala), apakah pekerjaan tegak (dinding), miring ke depan atau ke belakang. Pada pekerjaan menengadah ketebalannya $10 \mathrm{~mm}$ dan pekerjaan tegak ketebalannya $20 \mathrm{~mm}$. Apabila tebal total lebih dari $40-50 \mathrm{~mm}$, jaringan tulangan yang rapat diletakkan (menahan tegangan susut).

\section{H. Pemasangan Tulangan}

Tulangan dengan bantuan angker-angker dipasang pada jarak yang tepat dari permukaan beton. Dipilih agar jangan menerapkan lebar jaringan yang lebih kecil dari $100 \mathrm{~mm}$. Beton semprot harus selalu disemprotkan di sekeliling batang-batang. Jika ini tidak dilakukan, ada kemungkinan terjadi peretakan dan rongga-rongga di belakang tulangan dapat terjadi.

\section{Penyelesaian/Penghalusan}

Permukaan beton semprot selalu kasar, umumnya ini tidak merupakan masalah. Bila permukaan yang lebih licin diinginkan, maka perlu diberi ekstra lapisan penyelesaian/penghalusan atau finishing. Dianjurkan untuk lapisan beton semprot terakhir disemprotkan bahan lapisan yang halus dengan kadar semen yang lebih tinggi. Lapisan teratas ini dalam keadaan basah disemprotkan dan dapat digosok dengan gosokan sintetis sehingga di dapat lapisan dasar yang baik untuk ekstra lapisan penyelesaian (finishing)

\section{J. Perawatan-Kemudian}

Persentuhan yang terlalu cepat antara beton segar dengan udara luar, akan mengakibatkan beton kering. Oleh karenanya beton harus dibasahi selama sekitar 7 hari. Dianjurkan pula agar permukaannya ditutup dengan misalnya tenda gantung atau foil bahan sintetis. Kemungkinan permukaan beton dapat diberi perawatankemudian dengan penerapan suatu curing compound. Penambahan bahan sintetis dapat mengurangi persoalan pada perawatan kemudian. 


\section{KESIMPULAN}

Pada saat kebakaran, elemen struktur kolom dan balok banyak mengalami kerusakan-kerusakan, baik itu rompal atau perubahan susunan struktur dan kekuatannaya banyak bangunan setelah mengalami kebakaran, kekuatan (tegangan ijin), kekakuan dan mekanisme penjalaran gaya mengalami perubahan. Rompal pada beton sangat mempengaruhi kekuatan elemen struktur yang bersangkutan. Penurunan kekuatan yang terjadi dapat berlangsung sangat cepat.

Penanganan struktur setelah kebakaran dengan menggunakan cara beton semprot sangat cocok, karena gunite concrete merupakan suatu material yang mempunyai berat jenis hampir sama dengan berat jenis beton normal yaitu antara $2240 \mathrm{~kg} / \mathrm{m}^{3}$ sampai dengan $2320 \mathrm{~kg} / \mathrm{m}^{3}$ dan mempunyai daya lekat sangat tinggi pada beton atau tembok pada umumnya. Manfaat umum beton semprot ini adalah menawarkan keuntungan umum beton konvesional dalam banyak jenis konstruksi dan kerja rehabilitasi. Beton semprot sering kali lebih ekonomis dari pada beton konvensional karena tidak banyak membutuhkan bentuk cetakan/pembentuk (form work) dan hanya sedikit sarana untuk mencampur dan dapat ditempatkan pada tempat yang mudah dijangkau. Nilai penting dari beton semprot ini adalah kemampuannya untuk membentuk ikatan yang baik untuk sejumlah material.

Apliksai beton semprot memerlukan mesin-mesin khusus dan seorang tenaga ahli yang berpengalaman. Namun dalam perkteknya, mesin-mesin khusus tersebut dapat disederhanakan dan tenaga ahli yang dimaksud tidak terlalu khusus. Disamping tingkat kesulitan ini dapat diimbangi dengan keuntungan dalam apliaksi, fleksibility, kecepatan dalam penyelesaian dan kekuatan yang dihasilkan.

\section{DAFTAR PUSTAKA}

Anonim, Panduan Pengujian Tahan Api Komponen Struktur Bangunan Untuk Pencegahan Bahaya Kebakaran Pada Bangunan Rumah Dan Gedung, Direktorat Pekerjaan Umum, SKBI : 2. 3. 53. 1987, DPU, Jakarta 1987.

Anonim, Petunjuk Perencanaan Struktur Bangunan Untuk Pencegahan Bahaya Kebakaran Pada Bangunan Rumah Dan Gedung, Direktorat Penyelidikan Masalah Bangunan, SKBI : 2. 3. 53. 1987, DPU, Jakarta 1987.

Anonim, Laporan Penyelidikan Kelayakan Dan Kekuatan Struktur Bangunan Pasar Induk Wonosobo Pasca Kebakaran, PT. Yodya Karya, Semarang 2005.

D ja'far, Dwi, Tugas Akhir Perbaikan Struktur Beton Bertulang Pada Bangunan Setelah Kebakaran, Universitas Saint Al-Qur'an Wonosobo, 1997.

Fintel, Mark. Buku Pegangan Tentang Teknik Beton, PT. Pradya Paramita, Jakarta 1987.

Nurokhman, Diktat Kuliah Struktur Beton, Universitas Cokroaminoto Yogyakarta.

Sagel, Kole, Gideon Kusuma. Pedoman Pengerjaan Beton, SKNI T-15-1991-03, Jakarta 1997

Suhendro, Bambang. Teori Model Struktur Dan Teknik Eksperimental, Beta Offset, Yogyakarta 2000.

Tjokrodimulyo, Kardiyono. Teknologi Beton, Percetakan NAFIRI, Yogyakarta 1996. 